Spring 2009

\title{
Responding to the Economic Crisis
}

Jeffrey S. Guernsey

Cedarville University, jguernsey@cedarville.edu

Follow this and additional works at: http://digitalcommons.cedarville.edu/

business_administration_publications

Part of the Business Commons, and the Economics Commons

\section{Recommended Citation}

Guernsey, Jeffrey S., "Responding to the Economic Crisis" (2009). Business Administration Faculty Publications. 38.

http://digitalcommons.cedarville.edu/business_administration_publications/38

This Article is brought to you for free and open access by

DigitalCommons@Cedarville, a service of the Centennial Library. It has

been accepted for inclusion in Business Administration Faculty

Publications by an authorized administrator of

DigitalCommons@Cedarville. For more information, please contact

digitalcommons@cedarville.edu. 


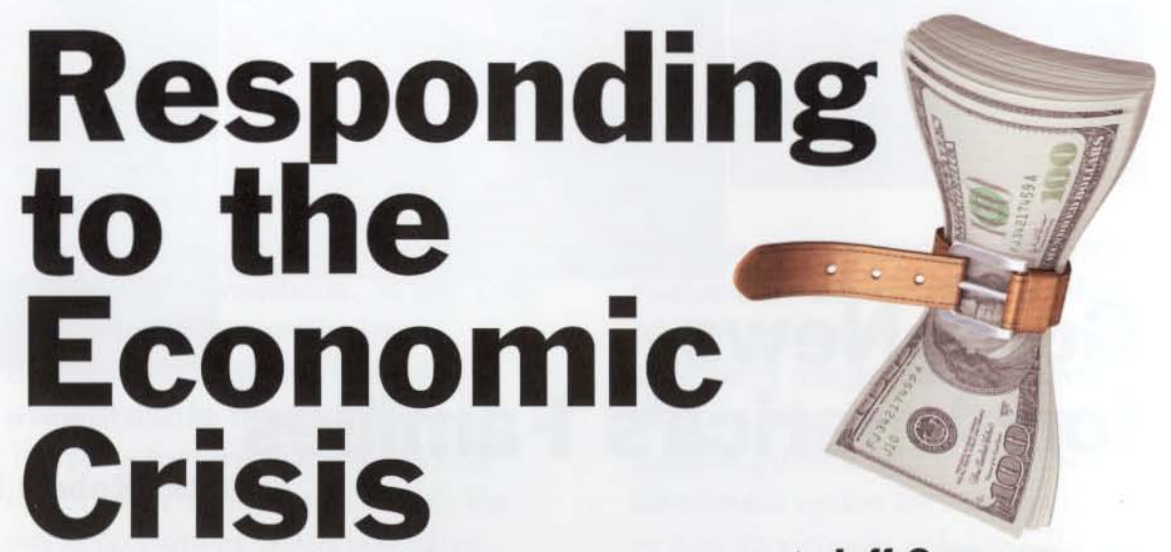

by Jeff Guernsey

Big-picture solutions to the economy have their place. But weathering the storm starts with personal financial management.

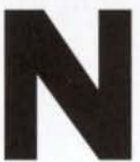

ervous? Apprehensive? For many of us, that doesn't even begin to cover what we're feeling. And the media and government have certainly given us enough material to worry about. The American economy isn't quite right, and we should be concerned. At the same time, though, it's important that we respond in a way that glorifies God and draws others to Him.

So, what can we do? I suggest seven responses Christians should have to the current economy.

\section{Live As Stewards}

This is foundational to how we think and act in regard to our money and possessions. If we believe we are the primary owners of our resources, we will hold on tightly and worry about keeping our things safe. However, if we recognize the truth that God owns everything (Psalm 24:1) and that our role is to be faithful stewards (1 Cor. 4:2), then we will hold our belongings with open hands.
As owner, God has the right to do with His possessions as He sees fit. Job reminds us, "The Lord gave and the Lord has taken away; may the name of the Lord be praised" (Job 1:21).

\section{Keep Giving}

Giving is a tangible reminder that what we have belongs to God. Words of the hymn "We Give Thee but Thine Own" speak of God's ownership and our giving in return:

"We give Thee but Thine own, Whate'er the gift may be:

All that we have is Thine alone, A trust, O Lord, from Thee."

When we give willingly, it keeps us from holding onto material things too dearly. As my wife reminded me recently, giving can protect us from selfishness.

In 2 Corinthians 8:1-5, Paul speaks to the Corinthian church about giving and commends the Macedonian believers: "In a great ordeal of affliction, their abundance of joy and their deep 


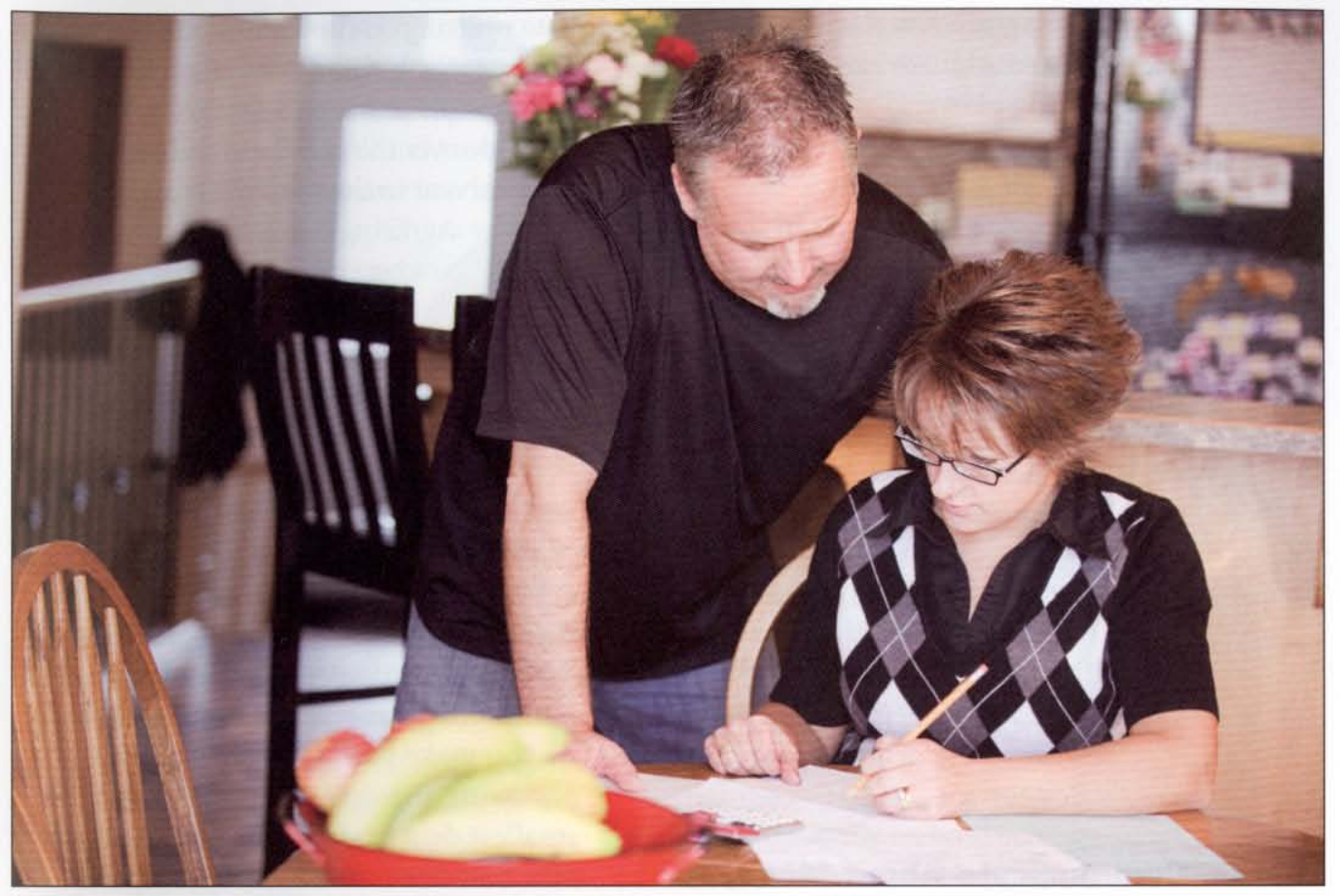

poverty overflowed in the wealth of their liberality." Then, after first offering themselves to the Lord, the Macedonians pleaded with others to participate "in the support of the saints."

Needs will likely increase because of this global economic hardship. As we have the opportunity, we ought to be unselfishly helping others. This is a time when we can demonstrate our love for those made in God's image and allow the Gospel to spread, not only through our words but also through our deeds.

\section{Spend Less Than You Earn}

This is always true, but particularly so in difficult financial times. Many of our current economic woes have been built on consumerism and overspending.

Spending less than one earns requires intentionality. It will likely include a spending plan or budget. One of my students once called a spending plan "an answer sheet to your finances."
A budget answers questions such as "What income is available?" and "How much money can I spend in various categories?" A handy rule in making a budget is $10 / 10 / 80$ - tithe 10 percent, save or invest 10 percent, and live on the remaining 80 percent.

Creating a budget is a good and necessary step, but it's not enough. You have to put it into practice. The individual or family should monitor actual results compared to the budget and then make choices based on that information, including changing spending priorities and habits. This might consist of reducing expenses such as restaurant visits, entertainment choices, and even decisions about housing.

Multiple resources are available to help establish a budget. Organizations such as Crown Financial Ministries and those led by Dave Ramsey and Mary Hunt have experience assisting others in this area. The local church may be a resource 
as well. Being accountable to a trusted friend or financial advisor can also make the spending plan real and achievable. than utilizing one's own funds. Borrowing obligates the borrower into the future and can limit his or her choices. Truly, "the rich rule over the poor, and the borrower is servant to the lender" (Prov. 22:7).

\section{Plan for an Emergency}

Sounds oxymoronic doesn't it? While we don't know when emergencies may occur, life happens - complete with unexpected events. The car will need a repair, the washing machine will need to be replaced, and items will wear out.

Begin now to build a minimum of three to four months of living expenses in readily available, liquid savings. A sufficient nest egg keeps an individual from having to use debt to cover those emergency costs.

\section{Communicate About Money Management}

Make sure someone knows how to access your financial information in the event of an emergency. Also, have a current will in place. These steps will enable that person to conduct financial matters in your absence, whether temporary or permanent. A trusted advisor can be very helpful in this regard as well.

If you are married, you should communicate and ultimately agree on major financial decisions as a couple. A marriage relationship is of much more value than any individual monetary resolution. Often the challenge in these discussions is not the money itself but the values and beliefs underlying the issue of money. Couples should strive to communicate honestly and work together on a common challenge.

\section{Get Out of Debt}

One element that has amplified the severity of the current economic condition is the use of credit - borrowing money rather
Agreeing to pay a debt is akin to making a financial vow. And Scripture instructs us to be very careful about the promises we make against tomorrow (Prov. 27:1, James 4:13-17).

First, pay off debt as much as possible, starting with any high-interest consumer debt. Dave Ramsey has a concept called the "debt snowball." He suggests listing all debts and looking at their total balances, minimum payments, and interest rates. As you make your required monthly payments, use extra money to pay off the smallest debt first. Once that is paid off, take that same monthly payment and apply it to the next debt on the list, until the debt snowball rolls down the list and all debts are paid off.

Second, avoid credit card debt. If your credit cards are causing you trouble, you're not alone. Outstanding credit card debt in the United States is approaching $\$ 1$ trillion - enough to average more than $\$ 4,300$ for each adult in America! Decide today to only use a credit card to buy what you can pay for in full on the next payment. But don't stop there. Commit to avoid using credit on items that lose their value, such as vacations, vehicles, and entertainment expenses.

If you can't control credit card use, try Ramsey's idea of a "plastectomy" performing "plastic" surgery by cutting up your credit cards. You can, in fact, survive in our culture without depending on credit.

\section{Do Not Fear or Worry}

With the economy the way it is, many are understandably concerned about 
retirement and investments. Although we should not minimize these concerns, we must recognize that worrying about these financial issues is a uniquely modern, Western-world phenomenon. Imagine asking rural farmers in China whether they are concerned about the balances of their retirement funds or discussing adjustable versus fixed-rate mortgages with a first-century believer. These questions would make no sense to them.

Fortunately, God's Word and His instructions to us are timeless. Scripture says that "if we have food and covering, with these we shall be content" (1 Tim. 6:8). In Hebrews 13:5-6, notice the close proximity of contentment, God's abiding presence, and a decision not to fear:

"Keep your lives free from the love of money and be content with what you have, because God has said,
'Never will I leave you;

Never will I forsake you.'

So we say with confidence,

'The Lord is my helper;

I will not be afraid.

What can man do to me?"”

Recessions and economic crises tend to come - and then pass. But even if that is not the case, we have a God who is the same yesterday, today, and forever, one who is fully faithful. $\mathbf{T}$

Jeff Guernsey currently serves as assistant professor of finance at Cedarville University, after working for more than 20 years in the banking industry. He earned an M.S. from lowa State University and a B.S. from Purdue University. He has been

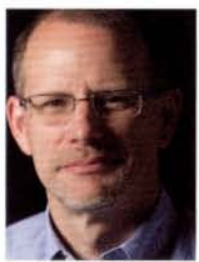
at Cedarville since 2003.

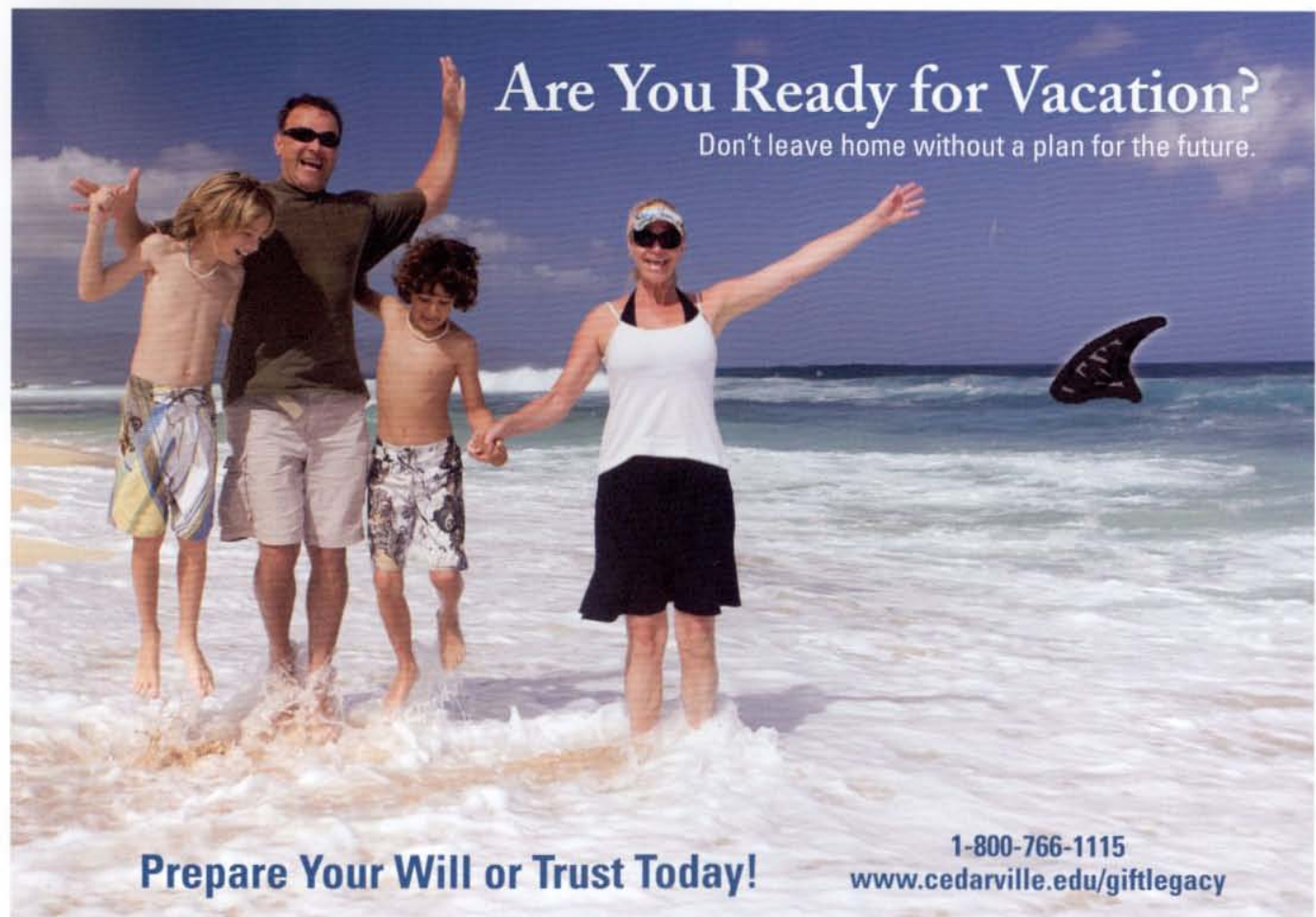

